\title{
Portrayal of fuzzy recharge areas for water balance modelling - a case study in northern Oman
}

\author{
A. Gerner, N. Schütze, and G. H. Schmitz \\ Institute of Hydrology and Meteorology, Technische Universität Dresden, Dresden, Germany \\ Correspondence to: A. Gerner (alexander.gerner@tu-dresden.de)
}

\begin{abstract}
The research project IWAS Oman aims at implementing integrated water resources management (IWRM) to a pilot area in $\mathrm{Al}$ Batinah, Oman. This requires - amongst others - a realistic assessment of groundwater recharge to the alluvial aquifer which obviously has to be based upon the extension of recharge areas. In this context, the subsequent investigation focuses on the role of vagueness as regards the portrayal of the areas that provide water for particular aquifers. For that purpose, concepts of fuzziness in spatial analysis are applied to describe possible extents of recharge areas.

In general, any water assessment is based on clearly delineated boundaries. However, in many cases, aquifer recharge areas are not clearly defined due to the nature of the study area. Hence, surfaces indicating a gradual membership to the recharge area of a particular aquifer are used in this investigation. These surfaces, which are based on available qualitative information, visualise a potential range of spatial extension. With regard to water balance calculations, functional relationships in tabular form are derived as well. Based on a regionalisation approach providing spatially distributed recharge rates, the corresponding recharge volume is calculated. Hence, this methodology provides fuzzy input data for water balance calculations. Beyond the portrayal of one singular aquifer recharge area, this approach also supports the complementary consideration of adjacent areas.
\end{abstract}

\section{Introduction}

In general, water resources in arid areas are mainly based on groundwater resources. Thus, a model based assessment of these resources is an important part of any integrated water resources management (IWRM). The subsequent investigation focuses on the assessment of recharge to an alluvial aquifer as a boundary condition for groundwater modelling.
An important recharge component, which Wilson and Guan (2004) term as mountain front recharge, is the underflow or subsurface outflow from the mountain region to the alluvial basin aquifer. This balance component is the outcome of several different hydrological processes in the mountain region. The task of quantifying the link between precipitation and mountain front recharge is crucial for water resources management in arid regions. Wheater (2007) provides a comprehensive introduction of the challenges of arid area hydrology based on several sample applications. He outlines the use of an integrated approach ranging from analysis of rainfall patterns to transmission losses in alluvial channels, and integrated surface-groundwater modelling. Scanlon et al. (2002) discuss a wide range of methods for quantifying recharge in the sense of water reaching the groundwater table. Andreo et al. (2008) developed a regionalisation approach for carbonate aquifers based on geomorphologic variables. Depending on the study area and data availability, selected methods or combinations of them may be appropriate for the assessment of the mountain front recharge.

Regardless which approach is used for the recharge quantification, knowledge about the spatial extent of the recharge areas is an essential basis for any water balance study. For example, former mass-balance studies in the study area of this investigation failed because no reliable data was available that could describe the largely karstified source areas of recharge to the alluvial aquifer on the Batinah plain (Weyhenmeyer et al., 2002). However, isotope studies provided well-founded qualitative information on recharge areas and flow paths of existing groundwater plumes in the Batinah region and the adjacent Daikiliyah region (Macumber, 1998; Macumber, 2003; Weyhenmeyer, 2000; Matter, 2006). An essential outcome of these studies is the fact, that recharge areas and groundwater flow paths in the Jebel Al Akhdar mountain range differ significantly from surface catchment boundaries. However, these studies do not completely answer 
the question of water drainage from significant parts of the study area to the two major groundwater plumes on the Batinah plain.

The aim of this study is the portrayal of possible extents of recharge areas by using fuzzy approaches in spatial analysis. Fuzzy approaches were recently introduced to spatial analysis in GIS environments (Morris and Kokhan, 2007; Lodwick, 2008; Petry et al., 2005; Jacobs, 2007). However, to the author's knowledge, there is no application in the field of water resources management up to date. Hence, this investigation demonstrates a way to transform available qualitative information into quantitative data, namely potential ranges of recharge volume to the existing groundwater plumes. The use as a fuzzy input for water balance modelling is discussed in this study.

\section{Methodology}

\subsection{Fuzzy theory and its application in spatial analysis}

In classical logic (CL) a proposition is either (absolutely) true or (absolutely) false. However, in fuzzy logic (FL), it is a matter of degree. In general, the latter way of reasoning is much closer to real life. Hence, Şen (2010) states "It is better to start with FL principles and arrive at a set of fuzzy conclusions than to conclude with classical logic (CL) (twovalued logic) a mathematical approach with only one crisp result, which may never appear in real life."

According to Şen (2010), fuzzy logic is based on linguistic variables which describe a universal set. They can be broken down into subsets by so called fuzzy words, which imply numerical values. The range of values and their gradual membership to the subset are described by membership functions (MF). In geographical analysis, thematic layers describe either discrete data, i.e. spatial distribution of certain categories with clearly delineated borders like land use classes or administrative units for example or continuous data, i.e. gradually changing numerical values like rainfall distribution or ground level elevation. However, comparable to the applications of fuzzy logic outlined above, geographic problems underlie vagueness as well. Transferring the basic concepts of fuzzy logic to spatial analysis, a thematic layer (e.g. landuse) can be seen as an analogue to a linguistic variable. However, the subsets (e.g. cropland or forrest) area referred to as fuzzy geographical entities (Lodwick, 2008) or fuzzy regions (Morris and Kokhan, 2007). In the subsequent text, they are referred to as fuzzy regions. Figure 1 shows an example for this, where the grey tone indicates the degree of membership. Accordingly, fuzzy regions are 2D-fuzzy membership functions with membership degrees $\mu(x, y)$ in relation to certain locations. As shown in the lower sketch in Fig. 1, a corresponding 1D-membership function can be derived as well. Hereby, the abscissa shows the value (in this context a measure of extension), while the ordinate indicates

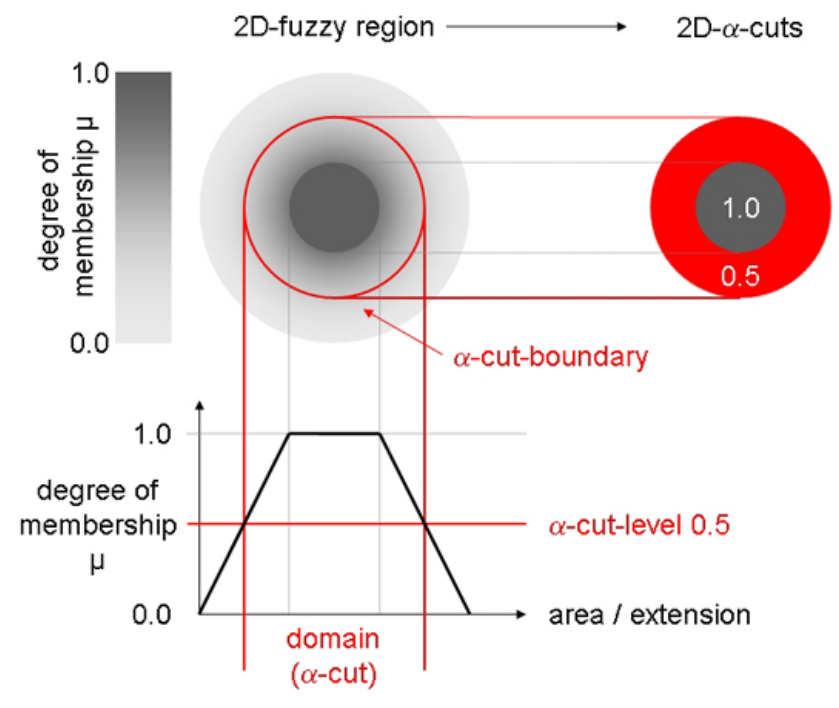

1D-membership function (MF)

Fig. 1. Representation of a $2 \mathrm{D}-$ fuzzy region and its $1 \mathrm{D}$-fuzzy set membership function (modified after Petry et al., 2005).

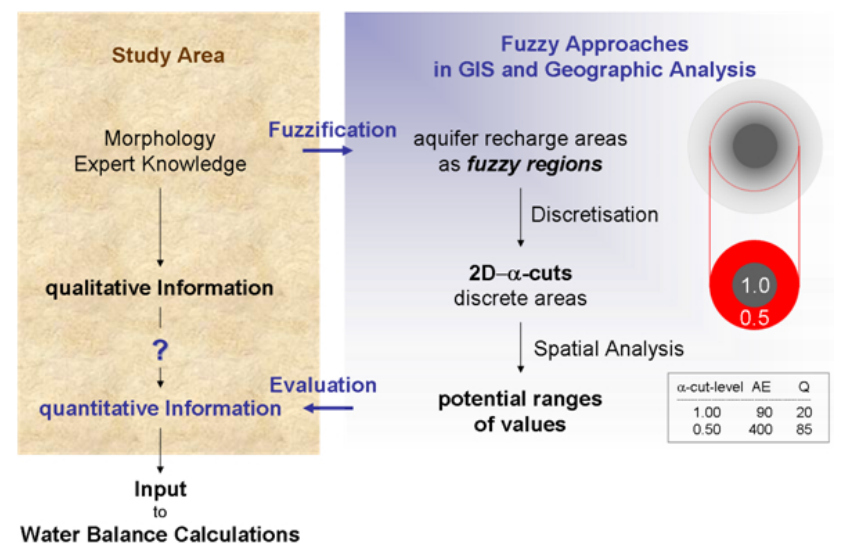

Fig. 2. The concept of fuzzy recharge areas.

the degree of membership $\mu(x)$. The $\alpha$-cut is the crisp subset with membership degrees $\mu(x)$ or $\mu(x, y)$ of at least $\alpha$. Hence, the (2D-) $\alpha$-cut of a fuzzy region is an area with a crisp $\alpha$-cut-boundary referring to a certain $\alpha$-cut-level.

\subsection{The concept of fuzzy recharge areas}

The concept of fuzzy recharge areas introduces the application of fuzzy regions to water resources management. Initially, quantitative information is requested for water balance calculations, but only qualitative information is assumed to be available. Hence, fuzzy recharge areas are an approach to transform qualitative expert knowledge referring to the hydrogeology of a study area into quantitative information, namely possible extensions of recharge areas $\mathrm{AE}$ or a corresponding water yield $Q$ (see Fig. 2). 
Recharge areas are described as raster surfaces (i.e. fuzzy regions $R$ ) with degrees of membership $\mu_{R i}(x, y)$ between 0 and 1 . Areas with $\mu_{R 1}(x, y)=1$ are certainly draining to the considered aquifer 1 . However, for raster cells with $\mu_{R i}(x, y)<1$, the subsurface drainage to an adjacent aquifer $\mathrm{m}$ is, in principle, possible as well. The concept includes the following steps:

\section{Expert knowledge}

- Gathering of information - e.g. geological setup of the study area, results of tracer or isotope studies, quality and quantity of the spring water, groundwater isoline maps etc.

- Data analysis and hypothesis generation about recharge areas and flow systems

\section{Fuzzification}

- Definition of outer boundaries (maximum extension of the fuzzy recharge areas)

- Definition of inner boundaries (assumptions on degrees of membership at certain sites)

- Data processing, i.e. translation of outer and inner boundaries (discrete data) into a continuous surface, referred to as fuzzy recharge areas

3. Consideration of adjacent areas

- Fulfillment of the complementarity constraint in regard to the consideration of adjacent areas according to Sect. 2.3.

\section{Evaluation}

- Discretisation: Processing of $2 \mathrm{D}-\alpha$-cuts by selection of raster cells with degree of membership equal or above the correspondent $\alpha$-cut-levels. As the case may be, adjacent areas are considered according to Sect. 2.3.

- Spatial Analysis: Calculation of recharge volume referring to $\alpha$-cut-levels - based on spatial overlay of fuzzy recharge areas and available spatial information on recharge (see Sect. 3.2 for example).

The approach results in potential ranges of values for spatial extent of recharge areas and according recharge volumes. Thus, it provides recharge estimates related to certain $\alpha$-cutlevels and hence fuzzy input to water balance calculations.

\subsection{Consideration of adjacent areas}

According to Sect. 2.1, a thematic layer "recharge areas" may consist of two fuzzy recharge areas $R_{1}$ (referred to as first order) and $R_{2}$ (referred to as neighbour) as subsets. By definition, the degree of membership $\mu_{\bar{R}}(x)$ of the complement $\bar{R}$ of the fuzzy region $R$ is $\mu_{\bar{R}}(x)=1-\mu_{R}(x)$. In a

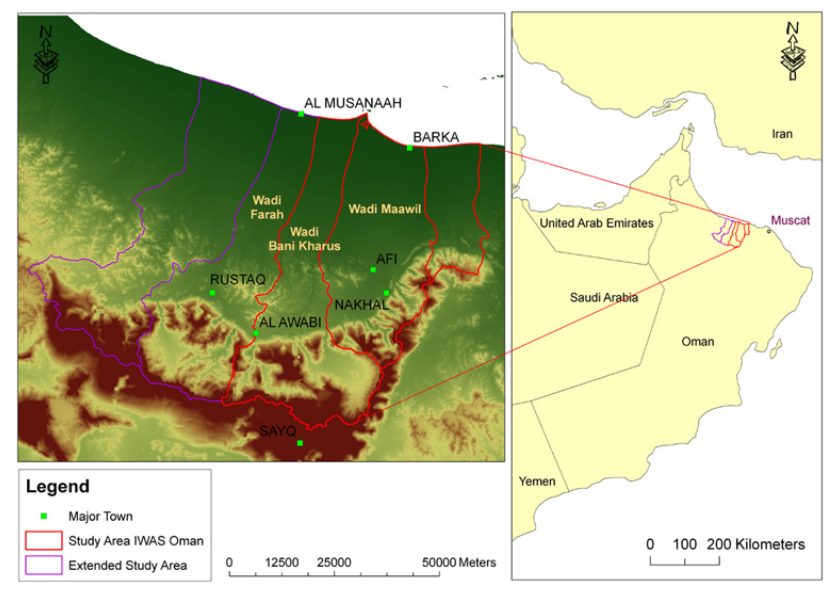

Fig. 3. The study area in the northern Oman.

fuzzy modelling approach in a narrow sense, this constraint is fulfilled by appropriate logical operations on fuzzy sets (see Şen, 2010 or Jabobs, 2007). Of course, it is possible, to fulfil it during fuzzification, e.g. by scaling the sum of the membership degrees all fuzzy recharge areas to one i.e. $\sum_{i=1}^{m} \mu_{R i}(x)=1$. However, in this investigation, no scaling is done during fuzzification. Rather, the complementary constraint is fulfilled during evaluation. Thus, a conditional fuzzy region for the neighbour has to be processed correspondent to the 2D- $\alpha$-cut-level of the first-order using the basic geometric operations complement (i.e. set-theoretic difference) and intersect (i.e. the minimum of the two layers).

\section{Application to the study area}

\subsection{Study area}

The study area is situated in the north of the Sultanate of Oman in the Al-Batinah region. Al-Batinah is a roughly $30 \mathrm{~km}$ broad coastal plain which extends over $250 \mathrm{~km}$ along the coast of the gulf of Oman north-westward of the capital Muscat. The Hajar mountain range borders to Al-Batinah from the south with peaks up to a height of $3000 \mathrm{~m}$. The pilot study area in the south-eastern part of Al-Batinah covers an area of about $2640 \mathrm{~km}^{2}$. However, due to the geological conditions an extended study area of about $5200 \mathrm{~km}^{2}$ is taken into account in this study (Fig. 3). According to AlHattaly and Al-Kindy (2008), high water demands of agriculture reqire more than $90 \%$ of the water resources. As a consequence, there is an ongoing overexploitation of the aquifer on the coastal plain. The main recharge areas of this aquifer are the high-altitudes of the Jebel Al-Akhdar mountain range (Weyhenmeyer, 2000). Figure 5 shows the prevalent geological units in the study area. The extent of the Jebel Al-Akhdar can be assumed to be more or less equal to the spreading of the Hajar Unit, which is dominated by limestone and dolomite. These carbonates are highly fractured and karst 


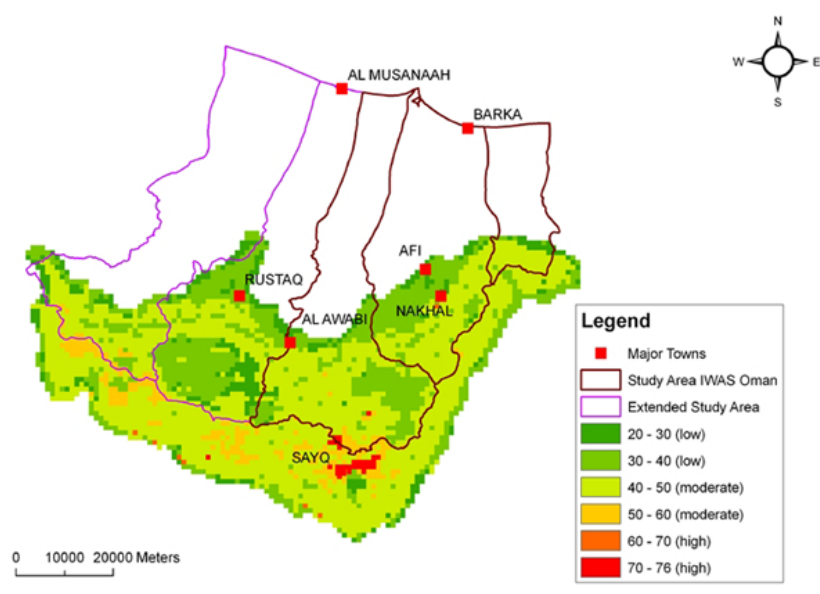

Fig. 4. APLIS recharge rates for the study area in $\%$ of annual precipitation.

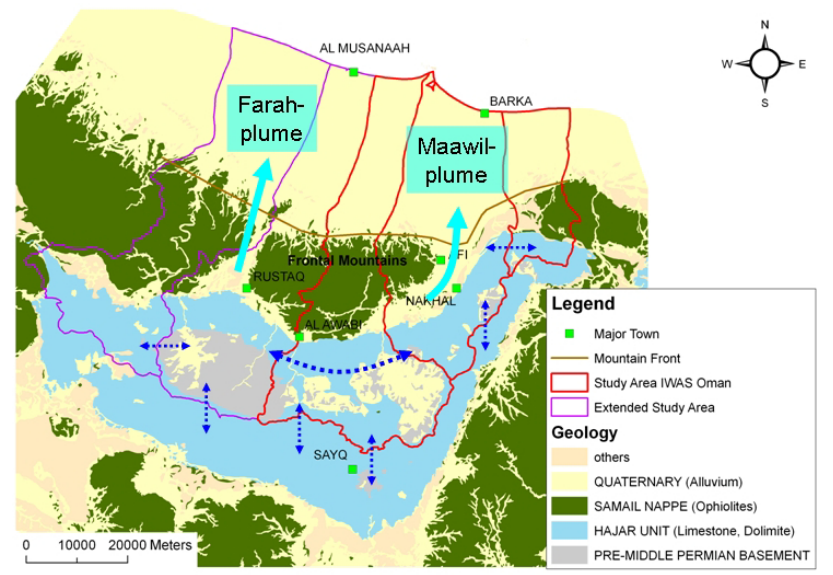

Fig. 5. Prevalent geological units based on the Geological Map 1:250000 (sheet NF4003-Seeb) and fuzziness in the extension of recharge areas.

\subsection{Provision of recharge values}

\subsubsection{Assessment of recharge rates}

The APLIS-method (Andreo et al., 2008) is a regionalisation approach based on data of several well investigated semi-arid catchments in southern Spain. Based on generally available geodata, it allows for estimation of recharge in carbonate aquifers, expressed as a percentage of annual precipitation. The five layers Altitude $(A)$, Slope $(P)$, Lithology $(L)$, preferential Infiltration landforms $(I)$ and Soil type $(S)$ are reclassified according to the APLIS-rating resulting in values ranging from 1 (low impact) to 10 (high impact). Thereafter, recharge rates are calculated as follows:

$R=(A+P+3 \cdot L+2 \cdot I+S) / 0.9$

The application of APLIS to the study area is based on the Geological Map of Oman (1:250 000, sheet NF4003, Seeb) which was provided by the Ministry of Rural Municipalities and Water Resources (MRMWR). A digital map of soil types was provided by the Ministry of Agriculture. Elevations and Slopes were derived from the ASTER-Digital Elevation Model (METI/NASA, 2009). Results for the study area are shown in Fig. 4.

\subsubsection{Areal precipitation and recharge volume}

Rainfall data for several stations was provided by the Ministry of Rural Municipalities and Water Resources (MRMWR). Based on this data, the mean annual precipitation was calculated. The highest rainfall amounts occur around the city of Sayq, where they also coincide with the highest recharge rates (Fig. 4). This is insofar important, because there is a high degree of vagueness in this area with regard to the subsurface drainage. A spatial overlay (i.e. multiplication) of recharge rates according to the APLIS-method 
and areal precipitation results in spatially distributed values for recharge volume. This layer, in the following referred to as recharge layer, finally provides a basis for quantitative conclusions based on the fuzzy recharge areas.

\subsection{Data processing of fuzzy recharge areas}

In the following, the procedure outlined in Sect. 2 is applied to the study area to illustrate the concept of fuzzy recharge areas. This exemplary application focuses on the main recharge areas of the two major plumes. Consequently, the plain north to the mountain front is out of consideration.

\subsubsection{Expert knowledge}

Based on the findings of the study area as above discussed, Fig. 5 shows markers symbolizing the two groundwater plumes and, furthermore, uncertainties in the spatial extension of the recharge areas. In summary, the processing of the fuzzy regions is, at this stage, based on the following boundary conditions:

- The Ophiolite areas do hardly contribute to the two major groundwater plumes. They are considered as a sort of zero-flux boundary, i.e. degree of membership is set to zero.

- Roughly it is assumed, that the upper catchment of Wadi Al-Farah does not contribute to the eastern Maawilplume. Conversely, the surface catchment of Wadi Maawil does not contribute to the western Farah-plume.

- To some extent, an inflow from areas south to the eastwest divide is possible. Notably, contributions from the Saiq plateau are supposable (Macumber, 2003). The maximum extent to this direction (with degree of membership $\mu=0$ ) is defined by the boundary of the Hajar Unit.

- The upper catchment of the Wadi Bani Kharus is considered as a transition zone with a high degree of vagueness with regard to the preferential flow direction.

\subsubsection{Fuzzification}

Figure 6 shows the data base for fuzzification, i.e. the interpolation of the fuzzy regions. The outer boundary is the assumed maximum extent of the main recharge areas. The inner boundaries are based on the qualitative information of the study area as discussed above. The mass points for assignment of the inner boundaries are based on a $2 \times 2 \mathrm{~km}$ raster of points. In general, critical raster points were selected based on their proximity to the above mentioned boundary conditions. However, individual cases, e.g. the supporting points in the Wadi Taww or Wadi Bani Ghafir, are advisable as well. Subsequently, a database with degrees of membership (Table 1) was joined. Triangulated Irregular Networds (TINs) of

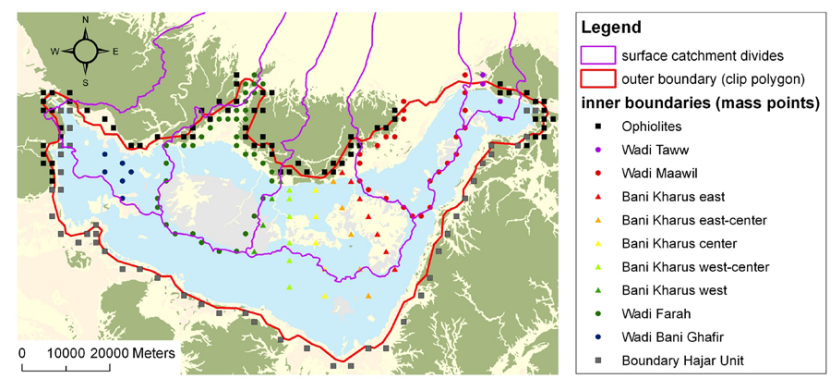

Fig. 6. Data base for fuzzification.

Table 1. Database for interpolation of the fuzzy recharge areas.

\begin{tabular}{lcc}
\hline Description & \multicolumn{2}{c}{ degree of membership $\mu$} \\
& MAAWIL & FARAH \\
\hline Ophiolite & 0 & 0 \\
Wadi Taww & 0.80 & 0 \\
Wadi Maawil & 1.00 & 0 \\
Wadi Bani Kharus east & 0.95 & 0.05 \\
Wadi Bani Kharus east-center & 0.75 & 0.25 \\
Wadi Bani Kharus center & 0.50 & 0.50 \\
Wadi Bani Kharus west-center & 0.25 & 0.75 \\
Wadi Bani Kharus west & 0.05 & 0.95 \\
Wadi Farah & 0 & 1.00 \\
Wadi Bani Ghafir & 0 & 0.80 \\
Southern boundary & 0 & 0 \\
\hline
\end{tabular}

the fuzzy regions were interpolated then using the 3D-Analyst in ArcGIS 9.3. Finally, these TINs were converted to ascii raster files with a spatial resolution of $1 \times 1 \mathrm{~km}^{2}$.

\subsubsection{Evaluation}

In the context of this investigation, evaluation means spatial analysis of extent and yield of recharge areas based on 2D- $\alpha$ cuts of the fuzzy recharge areas. This is mainly done by selection and aggregation of raster cells corresponding to a certain $\alpha$-cut-level. The results for the Maawil plume are shown in Fig. 7 (visualisation of $\alpha$-cuts) and Fig. 8 (extent and recharge volume as functions of the $\alpha$-cut-levels). Figure 9, however, shows the recharge per area instead of the recharge volume. It appears that the highest increase in recharge per area is between $\alpha$-cut-level 0.8 and $\alpha$-cut-level 0.5. The area in between covers the region around Sayq, which features the highest rainfall amounts and recharge rates, respectively (see Sect. 3.2). With regard to an integrated water balance assessment in the extended study area, conditional fuzzy recharge areas for the Farah plume were evaluated related to a certain $\alpha$-cut-levels of the first-order (Maawil plume) according to Sect. 2.3. The conditional results for the Farah plume are shown in Fig. 10. 

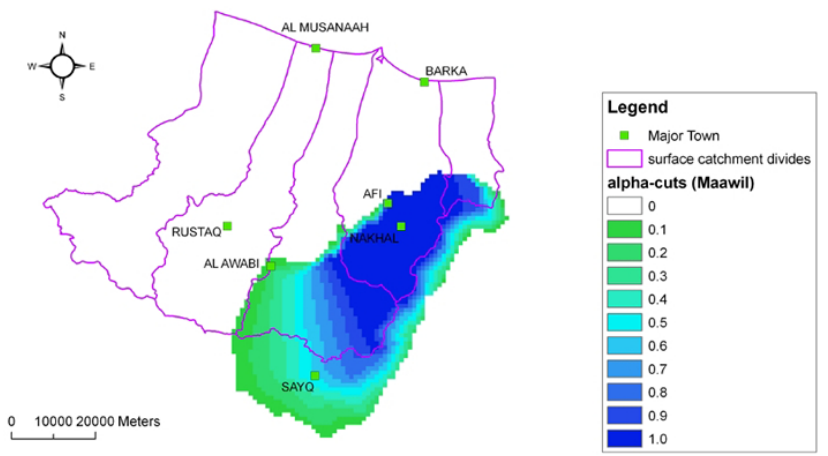

Fig. 7. $\alpha$-cuts for the Maawil plume.

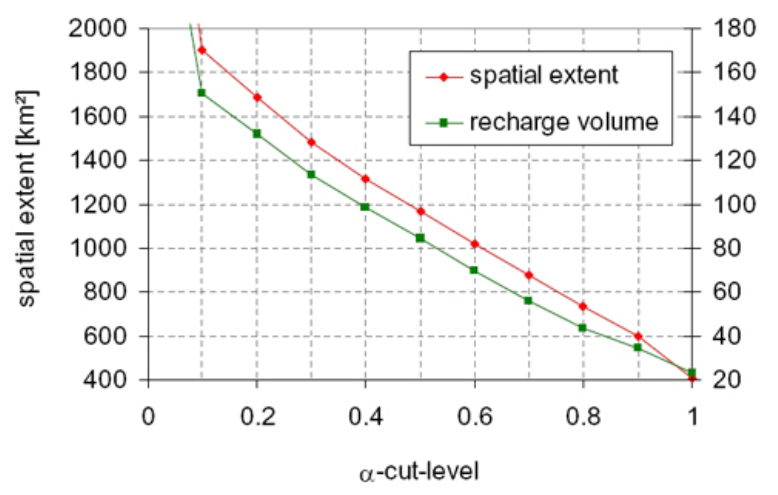

Fig. 8. Results (extent and recharge volume) for the Maawil plume.

\section{Discussion}

Figure 10 shows the resulting fuzzy recharge for the Maawilplume and the conditional fuzzy recharge volume for the neighbour Farah. Exemplarily, the derivation of crisp results for defined $\alpha$-cut-levels is demonstrated. Different combinations of $\alpha$-cut-levels for the fuzzy recharge areas result in different values for subsurface outflow from the mountainous region for each plume. Provided that the aquifer characteristics and further boundary conditions (i.e. sources and sinks) are reliable, then inverse groundwater modelling allows for a more exact identification of the recharge areas.

However, there are considerable uncertainties in each water balance component, i.e. recharge assessment, agricultural water demand and freshwater-saltwater interface. With regard to the role of the fuzzy recharge areas as one source of uncertainty for water balance calculations, two main sources of vagueness have to be taken into account in this study area (see Fig. 5). The first one, which is supposed to be quantitatively more important, is the east-west direction with focus on the transition zone south to the Frontal Mountains. The second one, the north-south direction, is the potential inflow or, more general, an exchange across the mountain ridge or the southern surface catchment divide, respectively. Although the latter one is supposed to be of minor importance, a misjudgement would affect the water balance for the

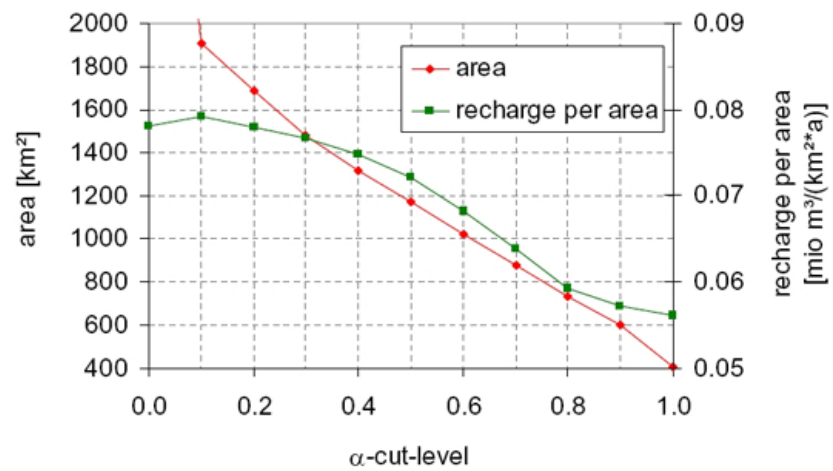

Fig. 9. Results (extent and recharge per area) for the Maawil plume.

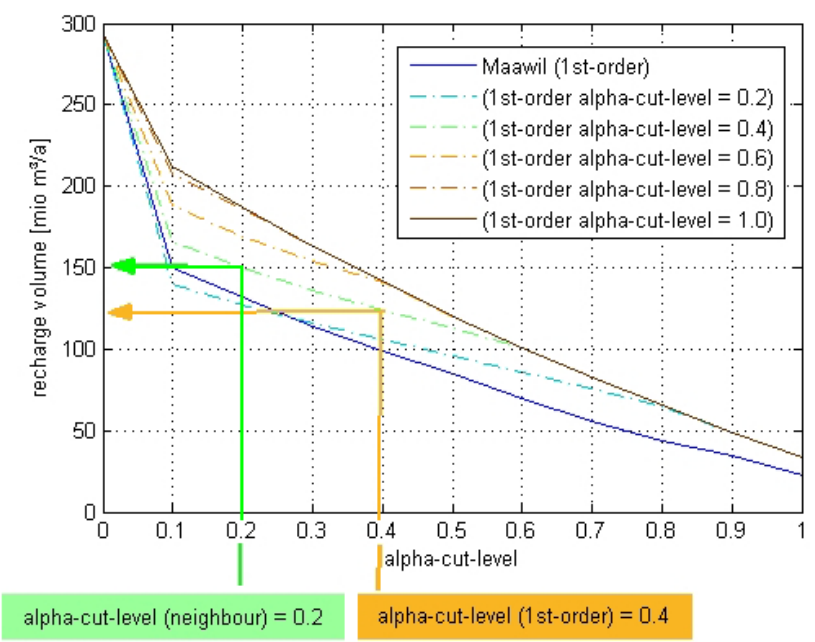

Fig. 10. Exemplary evaluation of results for $\alpha$-cut-level (first-order - Maawil $)=0.4$ and conditional $\alpha$-cut (neighbour - Farah $)=0.2$.

study area. A theoretical solution, which is in principle supported by the concept of fuzzy recharge areas, would be the integration of the aquifer system south to the study area into a macro scale water balance. However, this approach is opposed to the above discussed superposition of uncertainties in this study area and, hence, reserved for applications with an appropriate database. Besides, the quantitative results are based on interpretations of the study area during fuzzification and they are therefore subjectively biased. This corresponds to the statement of Jacobs (2007), whereupon fuzzification is, finally, quantification at the same time.

In summary, this study suggests that fuzzy recharge areas in combination with spatially distributed information on groundwater recharge can be used as tools to assess mountain front recharge in this study area, taking into account the characteristics and data availability of the study area. 
Acknowledgements. This manuscript was prepared within the research project IWAS funded by the German Federal Ministry of Education and Research (BMBF) under grant no. 02WM1028. The highly fruitful cooperation with the Ministry of Regional Municipalities and Water Resources is gratefully acknowledged. The authors thank Manfred Fink and another anonymous referee for their useful comments. Besides, the authors thank R. Ludwig and S. Berger for editing and Karin Grust for proofreading.

Edited by: R. Ludwig, K. Schulz, and M. Disse

Reviewed by: two anonymous referees

\section{References}

Al-Hattaly, S. and Al-Kindy, M.: Water Resources Assessment and the Evaluation of Expected Impacts of Climatic Change in Oman, Proceedings of the first International Conference Water Resources \& Climate Change in the MENA Region, 2-4 Nov 2008, Muscat, Sultanate of Oman, 2008.

Andreo, B., Vías, J., Durán, J. J., Jiménez, P., López-Geta, J. A., and Carrasco, F.: Methodology for groundwater recharge assessment in carbonate aquifers: application to pilot sites in southern Spain, Hydrogeol. J., 16, 911-925, 2008.

Jacobs, E.: Modellierungsmuster für GIS und Unschärfe - Fuzzy Methoden zur multiattributiven Raumbewertung (in German), Dissertation, Marburg, 2007.

Lodwick, W. A. (Ed.): Fuzzy Surfaces in GIS and Geographical Analysis, Theory, Analytical Methods, Algorithms, and Applications, CRC Press, Boca Raton, 2008.

Macumber, P. G.: The Cable Tool Program and Groundwater Flow in the eastern Batinah alluvial aquifer, Sultanate of Oman, Ministry of Water Resources, Muscat, 1998.

Macumber, P. G.: Lenses, Plumes and Wedges in the Sultanate of Oman: A Challenge for Groundwater Management, in: Water Resources Perspectives: Evaluation, Management and Policy, edited by: Alsharhan, A. S. and Wood, W. W., Elsevier, Science, Amsterdam, 349-370, 2003.
Matter, J. M., Waber, H. N., and Matter, A.: Recharge areas and geochemical evolution of groundwater in an alluvial aquifer system in the Sultanate of Oman, Hydrogeol. J.,14, 203-224, 2006.

METI/NASA: ASTER Digital Elevation Data, Retrieved: $14 \mathrm{Au}-$ gust 2009 from ftp://e4ft101u.ecs.nasa.gov, 2009.

Morris, A. and Kokhan, S. (Eds.): Geographic Uncertainty in Environmental Security, NATO Science for Peace and Security Series - C: Environmental Security, Springer, Dordrecht, 2007.

Petry, F. E., Robinson, V. B., and Cobb, M. A. (Eds.): Fuzzy Modelling with Spatial Information for Geographic Problems, Springer, Heidelberg, 2005.

Scanlon, B. R., Healy, R. W., and Cook, P. G.: Choosing appropriate techniques for quantifying groundwater recharge, Hydrogeol. J., 10, 18-39, 2002.

Şen, Z.: Fuzzy Logic and Hydrological Modelling, CRC Press, Boca Raton, 2010.

Stanger, G.: The Hydrogeology of the Oman Mountains, PhD Thesis, Open University Milton Keynes, 1986.

Weyhenmeyer, C.: Origin and Evolution of Groundwaters in the Alluvial Aquifer of the Eastern Batinah Coastal Plain, Sultanate of Oman, Dissertation, University of Bern, 2000.

Weyhenmeyer, C. E., Burns, S. J., Waber, H. N., Macumber, P. G., and Matter, A.: Isotope study of moisture sources, recharge areas, and groundwater flow paths within the eastern Batinah coastal plain, Sultanate of Oman, Water Resour. Res., 38, 1184, doi:10.1029/2000WR000149, 2002.

Wheater, H. S.: Hydrological processes, groundwater recharge and surface water-groundwater interactions in arid and semi arid areas, International Training Workshop on Groundwater Modeling in Arid and Semi-Arid Areas, G-WADI Workshop, Lanzhou, China, 11-15 June 2007, Course Material, 1-38, 2007.

Wilson, J. L. and Guan, H.: Mountain-Block Hydrology and Mountain-Front Recharge, Preprint of paper to be published in: Groundwater Recharge in A Desert Environment: The Southwestern United States, edited by: Phillips, F. M., Hogan, J., and Scanlon, B., AGU, Washington, D.C., 2004. 